\title{
Eco-friendly livestock management practices followed by tribal households of Narmada valley region of India
}

\author{
N. B. Patel ${ }^{*}$, S. D. Kavad ${ }^{1}$, T. K. S. Rao \\ Vanbandhu College of Veterinary Science \& A. H. Navsari Agricultural University, Navsari - 396450 (Gujarat), \\ INDIA \\ ${ }^{1}$ Krishi Vigyan Kendra, Waghai, Navsari Agricultural University, Navsari - 396450 (Gujarat), INDIA \\ *Corresponding author. E-mail: nbpatel@ rediffmail.com \\ Received: April 16, 2014; Revised received: August 14, 2014; Accepted: October 19, 2014
}

\begin{abstract}
A field survey was undertaken in Narmada valley region, four taluka of Narmada district of south Gujarat to collect first hand information on management practices of dairy animals followed by tribal peoples. The breeding, health care and milking management practices were studied using pre tested questionnaire through three stage sampling. Two villages, from four taluka were selected. From each village, 10 tribal farmers were selected randomly with a total of 80 respondents. Study revealed that maximum farmers $(41.30 \%)$ of this area were less educated belongs to middle age (53.80\% 30-50 years) category having medium size family (5-8 members). The estrus detection in cattle was based on sign and symptoms (100.0\%) rather than using teaser, moreover main symptoms for identification of animal in heat were bellowing and thin mucus discharge (58.80\%). The farmers $(86.30 \%)$ were observed to inseminate their animals within 12-18 hrs of heat. Method of breeding adopted in area was mostly (46.30\%) by combination i.e., Natural and artificial insemination (A.I.). Mostly the pregnancy diagnosis (P.D.) was practiced by $18.80 \%$ of the farmers. Dry period was more than three months in both indigenous cows $(92.40 \%)$ and buffaloes (91.20\%). Castration was performed in $72.70 \%$ of male animals of age more than 2 years. Vaccination was adopted by $53.80 \%$ of farmers. Regular de-worming was also practiced by 3.80 and $7.50 \%$ farmers for milch cow and calf respectively. Clean milk production was well adopted by farmers of the area. Knuckling (95.0\%) was common method of hand milking followed by full hand type $(3.80 \%)$ and stripping $(1.30 \%)$. The management practices followed by tribal farmers of area were exceptional for few facets however most of the practices required to be improved a lot.
\end{abstract}

Keywords: Breeding, Buffalo, Cattle, Health care, Management, Milking

\section{INTRODUCTION}

Reproduction is one of the most important considerations determining the profitability of dairy animal production (Gordon, 1996). Target of farmer is to maintain cyclic cow which become pregnant at appropriate time and deliver healthy calf each year with high milk production (Noakes et al., 2001). The research evidences suggest that cattle and buffaloes owners are not accustomed with scientific practices including breeding, health care and milking which ultimately reduce productivity at farmers door step (Sabapara et al., 2010). Calving Interval is very important aspect which is to be taken care sincerely for sustainable production. Common breeding problem faced by farmers are repeat breeding, late maturity and silent heat. Regular vaccination and de-worming is another important point in survival and productivity which ultimately affects income to a great extent. Milking management alone constitutes $60 \%$ of total farm activity and is highly essential for quality outcome. The dairy scenario in Narmada district of
Gujarat is depressing, because of low milk flow from this district to the market (Patel et al., 2013).

As the clean and quality milk is need of the time especially for the health conscious peoples, the present study was designed to gather information on different aspects of breeding, health care and milking management practices in holistic manner from dairy farmers of four different taluka of Narmada district of South Gujarat.

\section{MATERIALS AND METHODS}

This study was under taken using multistage stratified random sampling procedure to select two villages, from each taluka in four talukas, viz., Nandod, Tilakwada, Sagbara and Dediapada of Narmada district. From each village, 10 tribal farmers were selected randomly with a total of 80 respondents. The tribal were Vasava and Tadavi Bhils. All the farmers who are rearing at least two milch cattle or buffaloes were selected for the study. The information pertained to the status of the tribal dairy farmers, with respect to 
age, education, family size, land holding, affiliation to dairy organization, vocational diversification, herd size, herd composition, milk productivity, and the detailed practices followed by farmers with respect to breeding, health care and milking practices in survey areas were collected. The interview schedule developed for the study was used for collecting the information through personal interview and observation at animal shelter at the time of particular management practices going on, especially during milking time to see the hygienic status of milking procedures. With respect to management practices of dairy animals, there was no clear cut demarcation between four taluka of Narmada valley region of south Gujarat. Therefore, all the data recoded were averaged for all the four taluka further analyzed and interpreted.

\section{RESULTS AND DISCUSSION}

Socioeconomic profile of farmers: The majority of the dairy farmers $(53.75 \%)$ were in middle age-range (31-50 years). The young (10\%) were not attracted to dairying, because of easy availability of factory jobs in industrially resurgent south Gujarat. The greater part of the farmers $(41 \%)$ had primary level of education, followed by secondary level of education (35\%). Together, they constituted 76.25 percent. The mainstream of the farmers $(62.5 \%)$ were of middle family size (5-8). The nuclear and middle size families are involved in majority, in dairying operations. Commonly the farmers $(37.5 \%)$ owned 2.6 to 5.0 acres of land. $65 \%$ of farmers were members of dairy cooperative societies. However, $75 \%$ were dual/

Table 1. Characteristics of cross-section respondents.

\begin{tabular}{|c|c|c|c|}
\hline Parameters & Category & Total $(n=80)$ & Percentage \\
\hline \multirow[t]{3}{*}{ Age } & Young $(\leq 30$ yrs $)$ & 8.0 & 10.00 \\
\hline & Middle age (31-50 yrs) & 43.0 & 53.75 \\
\hline & Old age (Above 50 years) & 29.0 & 36.25 \\
\hline \multirow[t]{4}{*}{ Education } & Illiterate & 16.0 & 20.00 \\
\hline & Primary & 33.0 & 41.25 \\
\hline & Secondary & 28.0 & 35.00 \\
\hline & Above & 3.0 & 3.75 \\
\hline \multirow[t]{3}{*}{ Family size } & 1-5 members & 17.0 & 21.30 \\
\hline & 5-8 members & 50.0 & 62.50 \\
\hline & More than 8 members & 13.0 & 16.30 \\
\hline \multirow[t]{4}{*}{ Land holding } & Landless & 8.0 & 10.00 \\
\hline & Marginal (up to 2.5 Acre) & 17.0 & 21.25 \\
\hline & Small (2.6 to 5 animals) & 30.0 & 37.50 \\
\hline & Large $(>5$ Acre $)$ & 25.0 & 31.25 \\
\hline \multirow[t]{3}{*}{ Herd size } & Small (1-5) & 15.0 & 18.75 \\
\hline & Medium (6-10 animals) & 48.0 & 60.00 \\
\hline & Large (>10 animals) & 17.0 & 21.25 \\
\hline Types of Animals or & Indigenous cow & 13.0 & 16.25 \\
\hline \multirow[t]{6}{*}{ Herd composition } & Cross bred cow & 3.0 & 3.75 \\
\hline & Indigenous + cross bred cow & 6.0 & 7.50 \\
\hline & Buffalo & 9.0 & 11.25 \\
\hline & Indigenous cow + buffaloes & 43.0 & 53.75 \\
\hline & Crossbred cow + buffaloes & 2.0 & 2.50 \\
\hline & Indigenous + cross bred cow + buffaloes & 4.0 & 5.00 \\
\hline \multirow{4}{*}{$\begin{array}{l}\text { Affiliation to dairy } \\
\text { org. } \\
\text { Vocational } \\
\text { diversification }\end{array}$} & Dairy co-operative & 52.0 & 65.00 \\
\hline & Dairy co-operative + Other & 28.0 & 35.00 \\
\hline & Agriculture + livestock & 73.0 & 91.20 \\
\hline & Livestock + Others & 7.0 & 8.80 \\
\hline \multirow{3}{*}{$\begin{array}{l}\text { Milk yield (Lit/day)- } \\
\text { Indigenous cow }\end{array}$} & Less than 2 liters & 48.0 & 70.59 \\
\hline & 2-4 liters & 16.0 & 25.53 \\
\hline & Above 4 liters & 4.0 & 5.88 \\
\hline \multirow{3}{*}{$\begin{array}{l}\text { Milk yield (Lit/day)- } \\
\text { Crossbred cow }\end{array}$} & Less than 3 liters & 2.0 & 13.33 \\
\hline & 3-10 liters & 11.0 & 73.33 \\
\hline & Above 10 liters & 2.0 & 13.33 \\
\hline \multirow{3}{*}{$\begin{array}{l}\text { Milk yield (Lit/day)- } \\
\text { Buffalo }\end{array}$} & Less than 3 liters & 12.0 & 20.69 \\
\hline & 3-5 liters & 34.0 & 58.62 \\
\hline & Above 5 liters & 12.0 & 20.69 \\
\hline
\end{tabular}


Table 2. Breeding management practices followed by tribal farmers of Narmada region.

\begin{tabular}{|c|c|c|c|c|c|}
\hline S. N. & Parameters & $\begin{array}{l}\text { Frequency } \\
\text { (Percentage) }\end{array}$ & S. N. & Parameters & $\begin{array}{l}\text { Frequency } \\
\text { (Percentage) }\end{array}$ \\
\hline \multirow[t]{4}{*}{1.} & $\begin{array}{l}\text { Methods of heat detection } \\
\text { Symptoms }\end{array}$ & & 9. & $\begin{array}{l}\text { Dry period Indigenous } \\
\text { cow: }\end{array}$ & \\
\hline & Teaser bull & $80.0(100.0)$ & & Less than 2 months & $0.0(0.0)$ \\
\hline & & $0.0(0.0)$ & & $2-3$ months & $5.0(8.80)$ \\
\hline & & & & More than 3 months & $52.0(91.20)$ \\
\hline \multirow[t]{6}{*}{2.} & $\begin{array}{l}\text { Symptoms of heat } \\
\text { detection: }\end{array}$ & & 10. & $\begin{array}{l}\text { Breeding Records } \\
\text { maintained: }\end{array}$ & \\
\hline & Mucus discharge & $22.0(27.50)$ & & Yes & $16.0(20.0)$ \\
\hline & Mucus plus bellowing & $47.0(58.80)$ & & No & $64.0(80.0)$ \\
\hline & Frequent urination & $9.0(11.30)$ & & & \\
\hline & Mounting & $2.0(2.50)$ & & & \\
\hline & Licking and other & $0.0(0.0)$ & & & \\
\hline \multirow[t]{5}{*}{3.} & Breeding of females: & & 11. & CI (Crossbred cow): & \\
\hline & A.I. & $14.0(17.50)$ & & $12-13$ months & \\
\hline & Natural service & $29.0(36.30)$ & & $13-15$ months & $2.0(14.30)$ \\
\hline & Combination of both & $37.0(46.30)$ & & $>15$ months & $9.0(64.30)$ \\
\hline & & & & & $3.0(21.40)$ \\
\hline \multirow[t]{5}{*}{4.} & Insemination time: & & 12. & CI (Indigenous cow): & \\
\hline & Immediately after heat & $0.0(0.0)$ & & $12-13$ months & \\
\hline & Within $12-18 \mathrm{hrs}$ & $69.0(86.30)$ & & 13-15 months & $0.0(0.0)$ \\
\hline & After $18 \mathrm{hrs}$ & $11.0(13.80)$ & & $>15$ months & $9.0(13.60)$ \\
\hline & & & & & $57.0(86.40)$ \\
\hline \multirow[t]{5}{*}{5.} & Breeding after calving: & & 13. & CI (Buffaloes): & \\
\hline & $2-3$ months & & & $12-13$ months & $0.0(0.0)$ \\
\hline & 3-5 months & $7.0(8.0)$ & & 13-15 months & $5.0(8.80)$ \\
\hline & After 5 months & $16.0(20.0)$ & & $>15$ months & $52.0(91.20)$ \\
\hline & & $57.0(71.30)$ & & & \\
\hline \multirow[t]{4}{*}{6.} & Pregnancy diagnosis: & & 14. & Castration age: & \\
\hline & Practiced & $15.0(18.80)$ & & 6-12 months & $5.0(7.60)$ \\
\hline & Not practiced & $65.0(81.30)$ & & 12-24 months & $13.0(19.70)$ \\
\hline & & & & Above 24 months & $48.0(72.70)$ \\
\hline \multirow[t]{4}{*}{7.} & $\begin{array}{l}\text { Dry period Cross bred } \\
\text { cow: }\end{array}$ & & 15. & $\begin{array}{l}\text { Methods of castration: } \\
\text { Burdizzo method }\end{array}$ & \\
\hline & Less than 2 months & $1.0(7.70)$ & & Surgery & $48.0(72.70)$ \\
\hline & $2-3$ months & $9.0(69.20)$ & & Tradidtional & $2.0(3.0)$ \\
\hline & More than 3 months & $3.0(23.10)$ & & & $16.0(24.20)$ \\
\hline \multirow[t]{6}{*}{8.} & Dry period Indigenous & & 16. & Repeat breeding: & \\
\hline & cow: & & & Yes & $8.0(10.0)$ \\
\hline & Less than 2 months & $(0.0)$ & & No & $72.0(90.0)$ \\
\hline & 2-3 months & $(7.60)$ & & & \\
\hline & More than 3 months & $61.0(92.40)$ & & & \\
\hline & & 52.0 & & & \\
\hline
\end{tabular}

multiple members of other organizations, including dairy cooperative societies, while $25 \%$ were not members of any organization. Although five dairy cooperatives, viz., Vadodara Dairy, Bharuch Dairy, Surat dairy, Nivalda Dairy, and Amiyar Dairy operate in the district, their services do not reach to large number of tribal dairy farmers (Singh et al., 2008). Mixed farming (crop and livestock) system was followed by majority $(91.2 \%)$ of the farmers. The majority of the tribal farmers $(60 \%)$ had medium size herds (6-10). Most of the tribal farmers $(53.75 \%)$ maintained mixed flocks of indigenous cows and buffaloes. $16.25 \%$ of the farmers had indigenous cows, $3.75 \%$ had crossbred cows, and $11.25 \%$ were maintaining buffaloes. The average milk production of the indigenous cows maintained by majority of the tribal households $(70.59 \%)$ was less than 2 litres. The majority of tribal households $(73.33 \%)$ were maintaining crossbred cows, yielding 3-10 litres per day. Buffaloes in majority of tribal households (58.62\%) were yielding 3-5 litres per day.

Breeding management practices: The results regarding various breeding practices followed by the dairy owners are presented in Table 1. Comprehensive 
study of the results reveals that every one of the respondent from all the four taluka can identify the animals in estrus by using their symptoms (100.0\%) rather using teaser bull for the purpose. The main symptom of identification of animals in heat was bellowing plus mucus discharge $(58.80 \%)$ and mucus discharge $(27.50 \%)$ followed by frequent urination $(11.30 \%)$ and mounting $(2.50 \%)$ in all the four taluka of Narmada together. Some of the farmers are getting help from frequent urination for identifying heat was also suggested by Kokate and Tyagi (1991). In various farming zones of Punjab heat detection was observed primarily by a typical sign of let down and milk retention even after milking in buffaloes locally called as DOKA with vaginal discharge or overt symptoms of estrus (Brar and Nanda, 2004). Mainly farmers were checking their animals for heat in morning; however some of the farmers in all the four areas were also practicing inspection twice a day i.e., morning and evening. As far as breeding of female animals concerned majority of farmers $(46.30 \%)$ allow natural and artificial insemination simultaneously followed by natural service $(36.30 \%)$ and artificial insemination $(17.50 \%)$. Similar to present findings, farmers of Uttar Gujarat area take their animals especially buffaloes to A. I. (Artificial Insemination) center for insemination and also to breeding bulls for better conception (Malik et al., 2005). The present finding of high rate of natural

Table 3. Health care management practices followed by tribal farmers of Narmada district of Gujarat.

\begin{tabular}{|c|c|c|c|c|c|}
\hline S. N. & Parameters & Frequency (\%) & S. N. & Parameters & Frequency (\%) \\
\hline \multirow[t]{4}{*}{1.} & Vaccination against & & 5. & De-budding in calf & \\
\hline & FMD HS and BQ: & & & Yes & $7.0(8.80)$ \\
\hline & Yes & $43.0(53.80)$ & & No & $73.0(91.30)$ \\
\hline & Not & $37.0(46.30)$ & & & \\
\hline \multirow[t]{4}{*}{2.} & $\begin{array}{l}\text { De-worming in milch } \\
\text { animals: }\end{array}$ & & 6. & $\begin{array}{l}\text { Practice to control } \\
\text { ecto parasites: }\end{array}$ & \\
\hline & Regular & $3.0(3.80)$ & & Yes & $9.0(11.30)$ \\
\hline & Occasionally & $14.0(75.50)$ & & No & $71.0(88.80)$ \\
\hline & Not practiced & $63.0(78.8)$ & & & \\
\hline \multirow[t]{4}{*}{3.} & De-worming in calf: & & 7. & condition of & \\
\hline & Regular & $6.0(7.50)$ & & shed: & \\
\hline & Occasional & $25.0(31.30)$ & & Clean (dry) & $28.0(35.0)$ \\
\hline & Not practiced & $49.0(61.30)$ & & Dirty (wet) & $52.0(65.0)$ \\
\hline \multirow[t]{5}{*}{4.} & $\begin{array}{l}\text { Naval cord disinfection: } \\
\text { Yes }\end{array}$ & $0.0(0.0)$ & 8. & $\begin{array}{l}\text { Treatment of sick animal } \\
\text { by: }\end{array}$ & \\
\hline & No & $80.0(100.0)$ & & Local knowledge & $0.0(0.0)$ \\
\hline & & & & Livestock inspector & $36.0(45.0)$ \\
\hline & & & & Veterinary officers & $14.0(17.50)$ \\
\hline & & & & A.I. workers & $30.0(37.50)$ \\
\hline
\end{tabular}

Table 4. Milking management practices followed by tribal farmers of Narmada district Gujarat.

\begin{tabular}{|c|c|c|c|c|c|}
\hline S. N. & Parameters & Frequency (\%) & S. N. & Parameters & Frequency $(\%)$ \\
\hline \multirow{3}{*}{1.} & Frequency of milking: & & 6. & Teat dipping followed: & \\
\hline & Once in a day & $(0.0)$ & & Yes & $0.0(0.0)$ \\
\hline & Twice in a day & $80.0(100.0)$ & & No & $80.0(100.0)$ \\
\hline \multirow[t]{3}{*}{2.} & $\begin{array}{l}\text { Splashing of water on } \\
\text { udder before milking: }\end{array}$ & & 7. & $\begin{array}{l}\text { Cleaning of milking utensils: } \\
\text { Hot water }\end{array}$ & \\
\hline & Yes & $78.0(97.50)$ & & Tape water & $2.0(2.50)$ \\
\hline & No & $2.0(2.50)$ & & & $79.0(98.80)$ \\
\hline \multirow[t]{3}{*}{3.} & $\begin{array}{l}\text { Washing hand before } \\
\text { milking: }\end{array}$ & & 8. & $\begin{array}{l}\text { Testing of mastitis control: } \\
\text { Yes }\end{array}$ & \\
\hline & Yes & $78.0(97.50)$ & & No & $(0.0)$ \\
\hline & No & $2.0(2.50)$ & & & $80.0(100.0)$ \\
\hline \multirow[t]{3}{*}{4.} & Milking habit: & & 9. & Disposal of milk: & \\
\hline & Dry hand & $13.0(16.30)$ & & Co-operative society & $52.0(65.0)$ \\
\hline & Wet hand & $67.0(83.80)$ & & Vendors & $1.0(1.30)$ \\
\hline \multirow[t]{4}{*}{5.} & Milking methods: & & & Middle man & $9.0(11.30)$ \\
\hline & Full hand & $3.0(3.80)$ & & Home use & $18.0(22.50)$ \\
\hline & Knuckling & $76.0(95.0)$ & & & \\
\hline & Stripping & $1.0(1.30)$ & & & \\
\hline
\end{tabular}


service in buffaloes is in agreement with Sinha et al. (2010a); Kalyankar et al. (2004); Singh et al. (2004). This might be due to natural service was considered more reliable having less chance of failure and also high price of A.I. The failure of conception was frequently observed by farmers especially with artificial insemination. The low rate of conception with A.I. might be due to inability of farmers of exact time of ovulation and proper time A.I. (Rao et al., 2013). It was observed from their study on offered management practices to the cattles in western arid farming zones of Rajasthan, that majority of farmers bred their animals by natural means and fed their cattle with fruits of Bilama tree, Haldi with Bajra for animals suffering from anoestrus contion (Mathur and Panwar, 2001). Time of insemination after heat is very crucial aspect in conception; the farmers of the survey areas were inseminating their animals mainly within 12-18 hours $(86.30 \%)$ of heat manifestation however $13.8 \%$ of farmers inseminating their animals after 18 hours of heat. High insemination between 12-18 hours of heat shows the awareness and exposure of farmers of the Narmada towards scientific practices. This result was in agreement with Sabapara et al. (2010) who reported that the natural service or A.I. was performed between 12-24 hrs of heat detection by majority of respondents. As far as breeding after calving is concerned the most common practice was to breed the animals after 5 months, 3-5 months and 2-3 months of calving by $71.30,20.0$ and $8.80 \%$ of the farmers respectively. Pregnancy diagnosis after insemination is essential steps for reducing calving interval at door step of the farmers. However, only $18.80 \%$ of total respondents were practicing the P.D. in their animals. Calving interval (CI) was different in crossbred cow, indigenous cow and buffaloes. In majority of cross bred cow the calving interval was13-15 months $(64.30 \%)$ however in indigenous cows and buffalo the calving interval was more than 15 months in $86.40 \%$ and $91.20 \%$ respectively. More CI in buffaloes might be due to summer stress, silent heat problems and low conception rate. Dry period is also related to calving interval. In most of the cross bred cow the dry period is less i.e., 2-3 months $(69.20 \%)$ as compared to indigenous cow (92.40\%) and buffaloes $(91.20 \%)$ it is more than 3 months. Castration in male calf is common practice at the farmers house hold for efficient use draught power for the agriculture or cart purpose. The castration was practiced at age of 6-12 months, 12-24 months and more than 24 months by $7.60,19.7$ and $72.70 \%$ of farmers respectively. Commonly used method of castration by farmers was emasculotome i.e., Burdizzo crushing (72.70\%) followed by Traditional $(24.20 \%)$ and surgery (3.0\%). High level use of emasculotome crushing indicates awareness of farmers towards scientific practices. Bulls being used for breeding were reared by other progressive farmers to generate income or some of bulls are left by villagers free to be inseminated at easy access. Repeat breeding problems where three or more services were required for getting animal pregnant, was informed by $10.0 \%$ of farmers of Narmada district. Mostly the owners were utilizing second heat for the first insemination to the heifers. This shows understanding of sexual maturity in heifers by the farmers. It was very interesting to know that $20 \%$ of farmers were keeping the breeding records, however the records was not complete. Farmers were keeping records of peak milk yield, date of insemination and breed of bull or semen straw used. Most of the calving was observed during the summer season, this might be due to high level of care and management required during the time of winter.

Health management practices: The result of the health management practices followed by the farmers of the Narmada Valley region of Gujarat is presented briefly in table 2. Appraisal of result revealed that Prophylactic treatment against Foot and mouth disease (FMD), Hemorrhagic septicemia (HS) and Black quarter (BQ) was practiced by $53.80 \%$ of farmers however $46.30 \%$ of farmers not at all followed it. High level of vaccination practiced in area might be due to free of cost vaccination done by Dairy co-operative functional in this area. High level (51.10\%) of vaccination in rural area was also reported by Sinha et al. (2010a) in Bareily district of Uttar Pradesh as a result of free of cost vaccination provided by IVRI (Indian Veterinary Research Institute) Izatnagar. Similar finding was also reported by Prasad et al. (2002) in central dry zones of Karnataka states. However vaccination was not practiced in Kumaon hill area of Uttaranchal (Singh et al., 2004). De-worming is required at herd of farmers to protect animals from endo-parasites. De-worming was practiced in milch animals although it was performed regularly by only $3.80 \%$ of respondents and $17.50 \%$ of farmers were practicing de-worming occasionally moreover $78.80 \%$ of farmers not practicing de-worming completely. De-worming was also practiced in calves in regularly $(7.50 \%)$ or occasionally $(31.30 \%)$ by the farmers. The less number of farmers practicing de-worming might be due to lack of knowledge regarding the harm caused by parasitic load. Similar finding of restricted deworming practices was also reported by Sinha et al. (2010a) in Bareily. De-worming was also less in practice in rural areas of Haryana state and due to this reason calf mortality rate was very high especially in buffaloes (Singh and Singh, 2000). Naval cord disinfection of calf was very important practice in calf to protect the calf from joint ill disease in calf although it was not at all practiced by the farmers it show there less awareness towards scientific calf rearing. De-budding in calf was followed $8.80 \%$ of farmers. Ecto-parasite control is practiced by $11.30 \%$ farmers only in the survey area. Contrary to this finding high level of insecticide treated control of ecto-parasite was 
reported by Sinha et al. (2010a) in rural area of Bareily district of U. P. Ectoparasite problems were tackled by using mustard oil with salt or kerosene in rural house hold of Rajasthan (Gupta et al., 2000). As far as sanitary condition of shed is concern, it was clean in $35.0 \%$ farmers animal shed, however still $65.0 \%$ of farmers kept their animals in dirty shed. As far as treatment of sick animal is concerned it was followed mainly $(45.0 \%)$ by Livestock inspectors (LI) followed by A.I. workers $(37.50 \%)$ and Veterinary doctors $(17.50 \%)$. Animals treated by Veterinary doctors $(25.0 \%)$ was very less, this less awareness of farmers towards the scientific rearing. It is interesting to know that farmers in this area did not use local empirical treatment for suffering animals. This might be due to quick relief and better production revival from allopathic veterinary drugs as compared to local treatments.

Milk production practices: The result of the Milking management practices followed by the farmers of the four taluka of Narmada district region of Gujarat is presented in table 4. Perusal of result revealed that the frequency of milking was practiced twice a day by all $(100.0 \%)$ of the farmers. Splashing of water on udder or teats and washing of hand before milking was followed by most $(97.50 \%)$ of the farmers. Milking habit pursued by respondents in survey area was mostly $(83.80 \%)$ wet hand type and dry hand type milking was followed by only $16.30 \%$ of farmers. Wet hand type milking is one of the constraints in clean and hygienic milk production at farmers door step. Therefore farmers should be made acquainted to follow dry hand milking. Full hand type milking is best method of milking with respect to udder health however full hand milking followed by only $3.80 \%$ of farmers, this show their less understanding towards quality milk production. Most common method (95.0\%) of milking was knuckling type in area. Similar finding of high rate of Knuckling practice (74.4\%) was also reported by Sinha et al. (2010b). Teat dipping was not followed in the research area. Cleaning of milking utensils was followed by most of the farmers by tap water. Co-operative was functional in area and most of the milk was sent to the dairy co-operative only followed by home use, middle man and vendors. Testing of mastitis control was not practiced by any farmers.

\section{Conclusion}

It was concluded that common tribals residing in area were Vasava and Tadavi Bhils. A good number of farmers of this area were less educated, belonged to middle age category having medium size family with medium herd size. The estrus detection was solely based on sign and symptoms rather than by using teaser bulls. The time of insemination was 12-18 hrs of heat. The pregnancy diagnosis was followed by a small number of the farmers. Castration was performed in cattle chiefly by burdizzo castrator although at high age. Vaccination was practiced by about half of farmers. De-worming was practiced by the farmers, though it was not regular. Good sanitary condition was maintained in barn by around one third of dairy owners. Clean milk production was well adopted by the farmers; however milking method was challenging as they were using knuckling method for milk extraction. Post milking teat dipping was not at all practiced by the peasants. There are few aspects where they followed management practices carefully to certain extent; however most of the breeding, healthcare and milking practices oblige to be improved a lot in this area.

\section{REFERENCES}

Brar, P. S. and Nanda, A. S. (2004). Impact of conventional managemental practices on reproductive performance of rural buffaloes. Indian Journal of Animal Reproduction, 25 (2): 94.

Gordon, I. (1996). Controlled reproduction in cattle and buffaloes. $1^{\text {st }}$ edn. University press Cambridge, U.K.

Gupta, P., Singhal, A. and Tyagi, S. (2000). Indigenous practices in Animal husbandry. Asian Agri-History, 4 (1): 31.

Kalyankar, S. D., Gujar, B. V., Patange, D. D. G. R. and Lodhe, G. K. (2004). Adoption of dairy management practices of Marathwadi Buffaloes in their home tract. Indian Journal of Dairy Science, 57(6): 421.

Kokate, K. D. and Tyagi, K. (1991). Factors contributing to level of breeding gaps in cattle of Tribal mileu. Maharashtra Journal of Extension Education, 13: 209.

Malik, B. S., Meena, B. S. and Rao, S. V. N. (2005). Study of existing dairy farming practices in Uttar Pradesh. Journal of Dairying Foods \& Home Science, 24 (2): 91.

Mathur, P. and Panwar, J. S. (2001). Existing cattle management practices in arid western plain zone of Rajasthan. Rajasthan Journal of Extension Education, 2000 and 2001 (8 and 9), pp 22.

Noakes, D. E., Parkinson, T. J., England, G. C. W. and Arthur, G. H. (2001). Arthur's Veterinary Reproduction and Obstetrics. $1^{\text {st }}$ edn. Hercourt (India) Publication Limited, New Delhi.

Prasad, G., Venkatesh, Nataraju, M. S., Nagaraju, S. and Gopinathan, N. (2002). Knowledge of dairy management practices among the farmers of central dry zone in Karnatka state. The Veterinarian, 26:13.

Patel, N. B., Saiyed, L. H., Rao, T. K. S., Singh, R. R., Modi, R. J. and Sabapara, G. P. (2013). Status and constraints of Dairying in the tribal households of Narmada Valley of Gujarat-India. Animal Science Reporter, 7 (3):83-89.

Rao, T. K. S., Kumar, N., Kumar, P., Chaurasia, S. and Patel, N. B. (2013). Heat detection techniques in cattle and buffaloes. Veterinary World, 6 (6): 363-369, doi:10.5455/vetworld.2013. 363-369

Sabapara, G. P., Desai, P. M., Singh, R. R. and Kharadi, V. B. (2010). Breeding and health care management status of dairy animals in the tribal area of South Gujarat. Indian Journal of Animal Science, 74 (9): 997.

Singh, P. K., Durgaprasad, M. V. and Kollegal, M. (2008). Feasibility of independent dairy union in Narmada district of Gujarat - Report Institute of Rural Management, Ananad (IRMA), Anand, Gujarat. 
[www.vanbandhukalyanyojna.gujarat.gov.in]

Singh, P., Singh, M., Verma, M. L. and Jaiswal, R. S. (2004). Animal husbandry practices in Tarikhet block of Kumaon hill of Uttaranchal. Indian of Journal Animal Science, 74 (9): 997.

Singh, R. and Singh, N. (2000). Influence of socio-economic variables on adoption of buffalo calf rearing management practices in rural Haryana. Indian Journal of Animal Science, 70 (3): 325.

Sinha, R. R. K., Dutt, T., Singh, R. R., Singh, M. and
Bhusan B. (2010a). Studies on breeding and health care management practices in rural, semi-urban and urban areas of Bareily district of Uttar Pradesh. Indian Journal of Animal Production and Management, 26 (1 -2): 11-15.

Sinha, R. R. K., Dutt, T., Singh, Bhusan B., R. R., Singh, M. and Kumar, S. (2010b). Comparative studies of calf rearing and milking management practices in rural, semi-urban and urban areas of Bareilly district of Uttar Pradesh. Indian Journal of Animal Science, 80 (5): 483-85. 